Check for updates

Cite this: RSC Adv., 2018, 8, 2880

Received 25th October 2017

Accepted 5th January 2018

DOI: 10.1039/c7ra11760d

rsc.li/rsc-advances

\section{Polysulfone foam with high expansion ratio prepared by supercritical carbon dioxide assisted molding foaming method}

\author{
Zhengkun Li, Yingbin Jia and Shibing Bai (D)*
}

Polysulfone (PSU) is considered as an important candidate for the fabrication of high-performance microcellular polymers, but the preparation of PSU foam with a high expansion ratio still remains a big challenge worldwide. In this study, high expansion ratio PSU foam was successfully prepared by a supercritical carbon dioxide $\left(\mathrm{CO}_{2}\right)$ assisted molding foaming method. The foaming behavior of PSU under supercritical $\mathrm{CO}_{2}$ was systematically studied in various process conditions and different microcellular structures were created in PSU foams. The results showed that foaming temperature and $\mathrm{CO}_{2}$ concentration were the key factors to obtain microcellular foams with tailored microstructures. The cellular structure and expansion ratio of PSU foam obviously changed with different foaming temperatures. The expansion ratio and average cell size firstly increased and then decreased as foaming temperature increased. However, the cell density decreased and then remained stable as foaming temperature increased. The maximum expansion ratio of 11.0 was reached at the optimum foaming temperature of $200{ }^{\circ} \mathrm{C}$. Cellular structure and morphologies of the foam changed obviously at $\mathrm{CO}_{2}$ concentrations below $5 \%$ and remained stable at $\mathrm{CO}_{2}$ concentrations above $5 \%$. Finally, the prepared PSU foams exhibit excellent mechanical strength, good thermal conductivity, and superb heat retardancy, thus may have great potential application as a kind of substitute material in the electrical wire and cable industry, railway and steamer transportation, oil and gas platforms, military use and in other fields.

\section{Introduction}

Microcellular polymer foam, usually prepared by gas dispersion in a solid plastic, is widely used in industry, agriculture, construction, transportation and other fields. ${ }^{1}$ Compared with solid materials, there are many excellent properties of foamed polymers, such as light mass, special high strength, ${ }^{2,3}$ good heat insulation ${ }^{4,5}$ and soundproof performance. ${ }^{6}$ Currently, the most widely used general plastic foams mainly include polyurethane (PU), polystyrene (PS), polyvinyl chloride (PVC), polyethylene (PE), phenolic resin (PF) foam, and so on. However, because of the poor matrix performance of general plastics, these foams have a number of drawbacks such as being easy to burn,,$^{7,8}$ low mechanical strength, ${ }^{9}$ and poor thermal stability ${ }^{\mathbf{1 0}}$ etc., and therefore they cannot meet the requirements in some fields, especially in high-tech fields.

Compared with general plastics, special engineering plastics have excellent comprehensive properties. Polysulfone (PSU) is one of the most commonly used special engineering plastics, which has many outstanding properties, for instance, high modulus, strength and hardness, and especially an intrinsic flame retardant property. In addition, it also has outstanding

State Key Laboratory of Polymer Materials Engineering, Polymer Research Institute of Sichuan University, Chengdu 610065, China.E-mail: baishibing@scu.edu.cn thermal stability, chemical solvent resistance, and eximious aging resistance. Therefore, there is a broad application prospect for PSU in many fields, such as in aerospace, the automotive industry, insulation materials, microelectronics packaging, flexible circuit boards and other high-tech fields. ${ }^{11,12}$ PSU foam has also been used in the electrical wire and cable industry as an environmental-friendly material, and it is foreseeable that PSU foam will be a desirable manufacturing material in railway and steamer transportation, oil and gas platforms, military use and in other fields. However, as there are few related studies, it is urgent to research PSU foams and related applications. It is very difficult to prepare PSU foam because of its high processing temperature $\left(270-300{ }^{\circ} \mathrm{C}\right)$. Meanwhile, the foaming agent is difficult to be absorbed by PSU at this high temperature. The lack of high temperature foaming agents and the corresponding foaming equipment has become the biggest obstacle ${ }^{13}$ to prepare PSU foam. Therefore, some new methods should be developed.

Polymer foam prepared by supercritical fluid (SCF) is a newly developed green foam technology. There are many unique characteristics for supercritical carbon dioxide $\left(\mathrm{scCO}_{2}\right)$ such as high solubility and diffusivity. ${ }^{\mathbf{1 4}}$ In addition, it has other advantages like critical state $\left(31.26^{\circ} \mathrm{C}, 7.29 \mathrm{MPa}\right)$ is very easy to be realized. So, it can be used in the fields of foaming, especially engineering plastic foaming. $\mathrm{Ma} \mathrm{Z}^{15}$ has prepared 
polyphenylene sulfide (PPS)/polyether sulfone (PES) foam materials with $\mathrm{scCO}_{2}$ by solid batch foaming method, but there was a pretty small expansion ratio, which was only 3 . Sorrentino et al. ${ }^{16}$ processed polyphenylsulphone (PPSU) and PES foam through the batch foaming and solid-state foaming methods respectively, and found that PPSU and PES foam materials only had the largest expansion ratio at 4 with the optimum foaming conditions whether in the batch foaming method or in the solid-state method. Guo et al. ${ }^{17}$ reported the fabrication of PSU foams by solid-state foaming process and found the average cell size decreased with the increasing of the $\mathrm{CO}_{2}$ concentration in the polymer, but the expansion ratio was still low. PSU foam is usually prepared through batch foaming or solid-state foaming by $\mathrm{scCO}_{2},{ }^{18-20}$ but there exist some shortages: low $\mathrm{CO}_{2}$ solubility at foaming temperature or gas escape because of open environment during the foaming process. Owning to these problems, the foam density is larger, even close to unfoamed sample, and it is difficult to realize the industrialized production. Thus, how to produce high expansion ratio foams becomes a new urgent problem.

As we know, low temperature and high pressure will increase the $\mathrm{CO}_{2}$ absorption of polymers. If making PSU absorb more $\mathrm{CO}_{2}$ at low temperature and high pressure, and offering a closed environment by the mold to reduce the gas escape at the pressure holding stage, under these conditions there still remains a large amount of $\mathrm{CO}_{2}$ in the melt matrix at the foaming process. So the PSU foam with high expansion ratio will be obtained. However, few studies on foaming have been found through this method in a closed environment. In this work, the new method was used to prepare a series of PSU foams, and their structures, influence factors, and performance were investigated.

\section{Experimental section}

\subsection{Materials}

The PSU (Udel® PSU P-1700) used in this study was supplied by Solvay Company in the United States. Melt flow index (MFI) is 7 $\mathrm{g} / 10$ min (ASTMD-1238). Glass transition temperature $\left(T_{\mathrm{g}}\right)$ of the material was measured using a Q20 differential scanning calorimetry apparatus (TA, America), with a heating rate of $10{ }^{\circ} \mathrm{C} \mathrm{min}{ }^{-1} . T_{\mathrm{g}}$ was determined to be $187^{\circ} \mathrm{C}$ using the halfheight method. Density $(\rho)$ was $1.24 \mathrm{~g} \mathrm{~cm}^{-3}$. Carbon dioxide $\left(\mathrm{CO}_{2}\right)$ was supplied by Taiyu Airproduct with a purity higher than $99.9 \%$.

\section{2. $\mathrm{CO}_{2}$ adsorption}

The PSU pellets were first treated in a vacuum oven at $100^{\circ} \mathrm{C}$ for $6 \mathrm{~h}$ to remove the low molecular weight species, and then placed in a pressure vessel with a certain pressure and certain temperature for a certain time. Then samples were periodically taken out from the pressure vessel by quickly reducing the pressure to atmospheric pressure in the $30 \mathrm{~s}$ and immediately weighed on a Mettler AE240 analytical scale accurate to $\pm 10 \mu \mathrm{g}$ to measure gas uptake. The saturation pressure was $6 \mathrm{MPa}$, $8 \mathrm{MPa}, 10 \mathrm{MPa}$, and $12 \mathrm{MPa}$, the saturation temperature was
$25{ }^{\circ} \mathrm{C}, 45^{\circ} \mathrm{C}, 65^{\circ} \mathrm{C}$, and $85^{\circ} \mathrm{C}$ and the saturation time was $1 \mathrm{~h}$, $2 \mathrm{~h}, 4 \mathrm{~h}, 6 \mathrm{~h}, 9 \mathrm{~h}$, and $12 \mathrm{~h}$, respectively.

\subsection{Foaming}

In this study, a new foaming method was proposed, as shown in Fig. 1. First, the pellet sample was placed in a high pressure vessel at $25{ }^{\circ} \mathrm{C}$ and $12 \mathrm{MPa}$ for different time to make sure polymer absorb different concentration $\mathrm{CO}_{2}$. Subsequently, the sample was put out from the vessel and immediately transferred into the mold. After that the mold filled with the pellet sample was pressed to $20 \mathrm{MPa}$ in 10 seconds by the press vulcanizer, which was maintained at a high temperature-foaming temperature. 5 minutes was needed for the polymer to foam a supersaturation state $\mathrm{PSU} / \mathrm{CO}_{2}$ solution. The next step was opening mold and pressure released, just in this stage cell nucleation, growth, and solidification were accomplished instantly. In this study, the foaming temperature was $170{ }^{\circ} \mathrm{C}, 180{ }^{\circ} \mathrm{C}, 190{ }^{\circ} \mathrm{C}$, $200{ }^{\circ} \mathrm{C}, 210^{\circ} \mathrm{C}$ and $220^{\circ} \mathrm{C}$, and the saturation time was $1 \mathrm{~h}, 2 \mathrm{~h}$, $4 \mathrm{~h}, 6 \mathrm{~h}, 9 \mathrm{~h}$, and $12 \mathrm{~h}$, respectively. The size of the mold was $6 \mathrm{~mm} \times 100 \mathrm{~mm} \times 100 \mathrm{~mm}$.

\subsection{Characterizations}

2.4.1. Apparent density. The density of each sample was determined according to ASTM D792 using Shimadzu MH-120S. Samples were allowed to desorb for at least one week before density measurement being performed in order to eliminate the effect of residual $\mathrm{CO}_{2}$. Three measurements were performed for each sample.

2.4.2. Scanning electron microscope (SEM). The morphologies of PSU foams were investigated by an Inspect F (FEI) SEM instrument at 0.5 Torr and $20 \mathrm{kV}$. The samples were freeze fractured in liquid nitrogen and sputter coated with $\mathrm{Au} / \mathrm{Pd}$. Image analysis on the SEM photographs was conducted using the software Nano-Measurer to obtain the average cell size and cell density. The average cell size was determined by taking at least 100 cells from the data of SEM observation. The cell density $N_{\mathrm{f}}$ was calculated using the following equation

$$
N_{\mathrm{f}}=\left[\frac{n M^{2}}{A}\right]^{\frac{3}{2}}
$$

where $n$ is the number of cells, $A$ is the area of the micrograph in $\mathrm{cm}^{2}$, and $M$ is the magnification factor.

2.4.3. High pressure differential scanning calorimetry (HPDSC). Thermal analysis of the samples under $\mathrm{CO}_{2}$ was performed by a high pressure DSC (Sensys Evo, Setaram, France). Firstly, the $\sim 20 \mathrm{mg}$ specimens were placed into the cell and were pressurized to experimental pressure. After waiting for 30 min to absorb enough $\mathrm{CO}_{2}$, it was heated to $250{ }^{\circ} \mathrm{C}$ at the $10{ }^{\circ} \mathrm{C} \min ^{-1}$ heating rate under $\mathrm{CO}_{2}$ atmosphere and kept at $250{ }^{\circ} \mathrm{C}$ for $5 \mathrm{~min}$ to eliminate the thermal and stress history. Thereafter, the sample was cooled to $40{ }^{\circ} \mathrm{C}$ and reheated to $250{ }^{\circ} \mathrm{C}$ in sequence at the $10{ }^{\circ} \mathrm{C} \mathrm{min}^{-1}$ rate.

2.4.4. High pressure capillary. The capillary rheology test was carried out on a Rosand RH7D high-pressure capillary rheometer (Malvern Instruments, UK). After absorbing a certain 

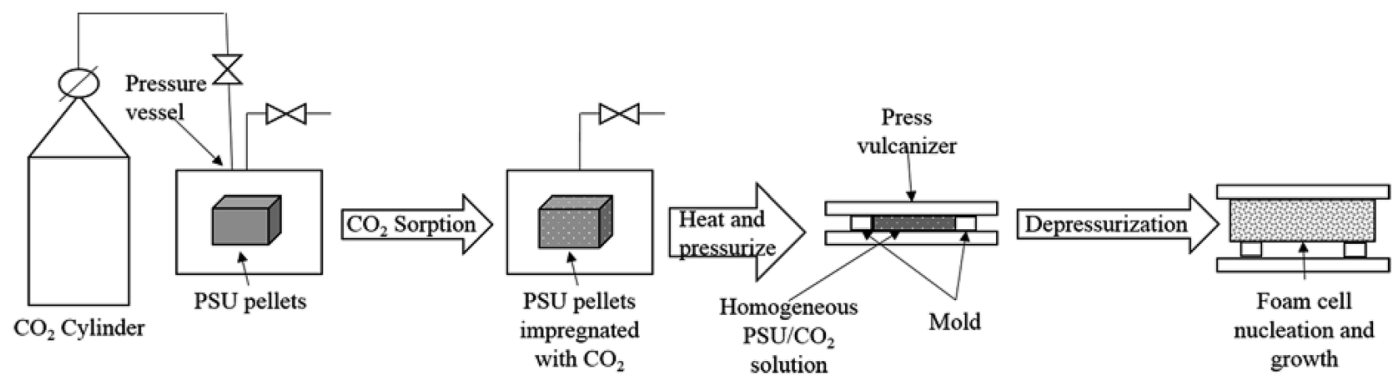

Fig. 1 Procedure and mechanism diagram of new foaming method.

$\mathrm{CO}_{2}$, the PSU pellets were taken out from the pressure vessel and immediately placed into the charging barrel of high pressure capillary rheometer. In order to avoid gas escape, ethylenevinyl acetate copolymer (EVA) was used to seal both sides of the charging barrel of the device and also the long die $(\mathrm{L} / \mathrm{D}=16)$ was used in this test. Then, the measurements were taken at a shear rate range of $50-3000 \mathrm{~s}^{-1}$. The PSU pellets with different $\mathrm{CO}_{2}$ concentrations could be got by controlling saturation time, saturation pressure and saturation temperature. The temperature of high pressure capillary rheometer was $280^{\circ} \mathrm{C}$.

2.4.5. Mechanics performance. The mechanics performances were recorded with an Instron 5576 (Instron Co., Ltd., United States). For compressive strength testing, samples were cut into a rectangular block $\left(100 \times 100 \times 50 \mathrm{~mm}^{3}\right)$ and tested at a crosshead speed of $2 \mathrm{~mm} \mathrm{~min}^{-1}$ according to GB/T 8813-2008/ ISO 844:2004. The tensile strength was completed according to GB/T 9641-1988/ISO 1926-1979 at a speed of $5 \mathrm{~mm} \mathrm{~min}^{-1}$ with a standard sample. Five measurements were performed for each sample.

2.4.6. Flame retardancy and thermal performance. The limiting oxygen index (LOI) was measured on a JF-5 oxygen index instrument (Jiangning Analysis Instrument Co., China) with specimen dimensions of $130 \times 10 \times 10 \mathrm{~mm}^{3}$ according to ASTM D 2863. The heat distortion temperature (HDT) of the foams was examined by a heat distortion temperature machine (HDV2, ATLAS, USA) with specimens according to ASTM D64895. The thermal conductivity of the foams was measured with a Hot Disk thermal analyzer (2500-OT, Hot Disk AB, Sweden).

\section{Results and discussion}

\section{1. $\mathrm{CO}_{2}$ adsorption}

The $\mathrm{CO}_{2}$ concentration of PSU was investigated under a wide range of processing conditions. Fig. 2a and b respectively shows $\mathrm{CO}_{2}$ adsorption in PSU at different saturation temperatures under $12 \mathrm{MPa}$ and saturation pressures at $45^{\circ} \mathrm{C}$. It can be seen that the $\mathrm{CO}_{2}$ concentration in the PSU increased and then reached equilibrium with the increasing time. After reaching equilibrium, the $\mathrm{CO}_{2}$ concentration decreased with the temperature increasing. When saturation temperature was $25{ }^{\circ} \mathrm{C}$, the $\mathrm{CO}_{2}$ concentration was $8.68 \%$, nearly two times of that at $85{ }^{\circ} \mathrm{C}$. Thus, it can be predicted that the $\mathrm{CO}_{2}$ concentration in the polymer is pretty small when the temperature is up to foaming temperature, which will have a great influence on foaming. As for the influence of saturation pressure, it can be seen that the $\mathrm{CO}_{2}$ concentration increased with the pressure increasing. Especially, the $\mathrm{CO}_{2}$ concentration at $12 \mathrm{MPa}$ was also nearly two times of that at $6 \mathrm{MPa}$. This meant it is beneficial for foaming at a higher pressure atmosphere. However, there was an open environment or gas escape in traditional foaming methods. While in the new foaming method, a closed environment was offered by the mold to reduce the gas escape at the pressure holding stage, under these conditions there still remains a large amount of $\mathrm{CO}_{2}$ in the melt matrix at the foaming process. So the PSU foam with high expansion ratio will be obtained. In order to increase the $\mathrm{CO}_{2}$ concentration in the polymer, the saturation pressure
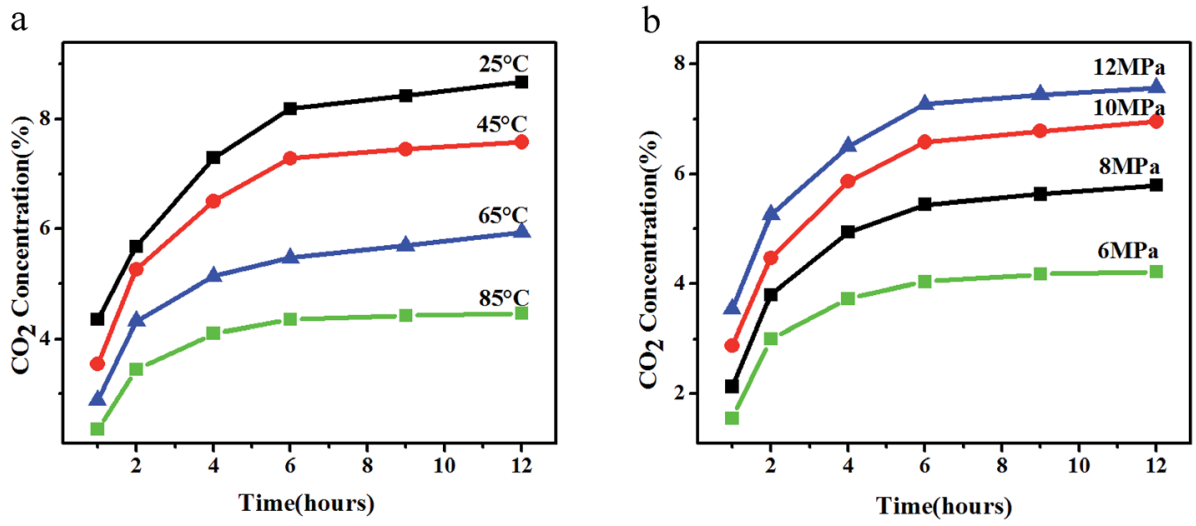

Fig. $2 \mathrm{CO}_{2}$ adsorption in PSU at different saturation temperatures under $12 \mathrm{MPa}$ (a) and different saturation pressures at $45^{\circ} \mathrm{C}$ (b). 


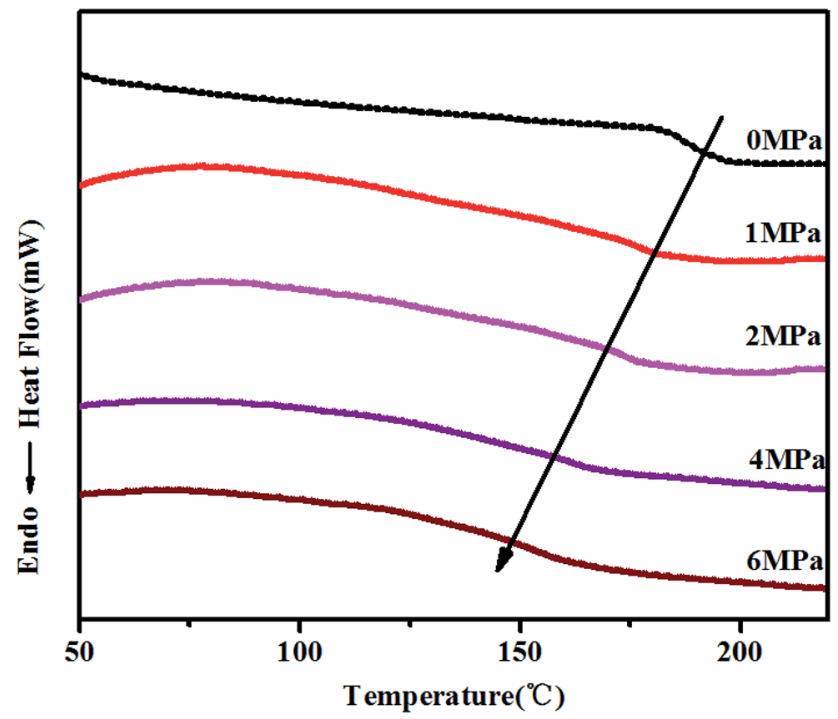

Fig. 3 HP-DSC heating curves of PSU under different $\mathrm{CO}_{2}$ pressure.

$12 \mathrm{MPa}$ and the saturation temperature $25{ }^{\circ} \mathrm{C}$ have been chosen in the experiment.

\section{2. $\mathrm{CO}_{2}$ plastication}

Fig. 3 is HP-DSC heating curves of PSU under different $\mathrm{CO}_{2}$ pressures. It can be clearly found that there is a significant decrease of the $T_{\mathrm{g}}$ under $\mathrm{CO}_{2}$. As $\mathrm{CO}_{2}$ is a Lewis acid, the carbon atom lack of electronic in the $\mathrm{CO}_{2}$ molecule can become electron acceptor, ${ }^{21}$ thus there will be a special interaction between $\mathrm{CO}_{2}$ molecule and some groups like phenyl group, sulfuryl group. ${ }^{22}$ And $\mathrm{CO}_{2}$ as a small molecule plasticizer, can magnify the distance between PSU molecules, augment the free volume of the molecules and weaken attraction between the molecules, and thus increase mobility between polymer molecular chains. Thus, there is a big reinforce for polymer plastication and foaming temperature significantly decreases.

Table 1 is $T_{\mathrm{g}}$ data from HP-DSC heating curves, and the influence of $\mathrm{CO}_{2}$ on the $T_{\mathrm{g}}$ can be received. Under $\mathrm{CO}_{2}$ pressure from $1 \mathrm{MPa}$ to $6 \mathrm{MPa}$, the $T_{\mathrm{g}}$ linearly decreased with the increase of $\mathrm{CO}_{2}$ pressure, which meant that the processing properties has been greatly promoted by the addition of $\mathrm{CO}_{2}$.

Polymer viscosity is an important influence factor in polymer foaming ${ }^{23,24}$ and high pressure capillary test was done in this research. As shown in Fig. 4, at the $\mathrm{CO}_{2}$ concentration below $5 \%$, the polymer shear viscosity reduced with the increase of $\mathrm{CO}_{2}$ concentration, which was in agreement with the previous reports. ${ }^{25}$ However, when at $\mathrm{CO}_{2}$ concentration above $5 \%$, the polymer shear viscosity kept stable with the increase of $\mathrm{CO}_{2}$ concentration. This indicated that too high $\mathrm{CO}_{2}$ concentration

Table 1 The glass transition temperature data from HP-DSC heating curves

\begin{tabular}{llllll}
\hline Pressure (MPa) & 0 & 1 & 2 & 4 & 6 \\
$T_{\mathrm{g}}\left({ }^{\circ} \mathrm{C}\right)$ & 187 & 177 & 171 & 160 & 152
\end{tabular}

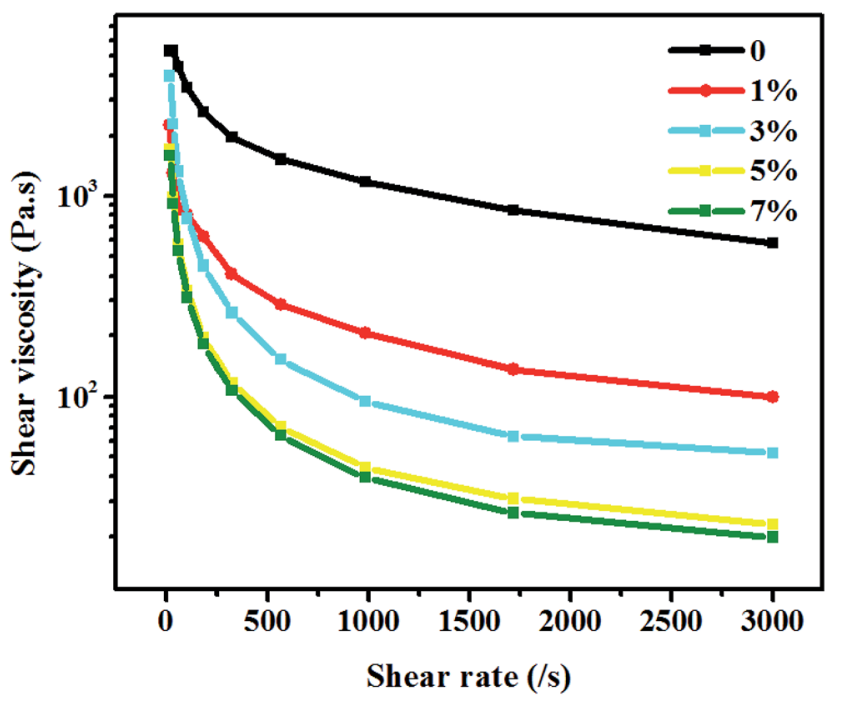

Fig. 4 High pressure capillary curve of PSU at different $\mathrm{CO}_{2}$ concentrations with temperature $\left(280^{\circ} \mathrm{C}\right)$.

didn't influence the viscosity of PSU. But the viscosity had an obvious decrease under the effect of $\mathrm{CO}_{2}$. So there would be a perfect way for PSU to solve the problem of difficult processing and to provide the appropriate foaming agent.

\subsection{Foaming}

3.3.1. Influence of temperature. One of crucial influence factor for polymer foaming is the foaming temperature in the foaming process. ${ }^{26,27}$ There are different viscosities and melt strength for polymer at different temperatures, which will form diverse cellular structures. There is a range of temperature to foam for every polymer and it would not foam at too high or low temperature. Fig. 5 shows the SEM pictures of PSU foams at different foaming temperatures. With the increase of temperature, there was an obvious change about cell structure. At lower temperature like $170{ }^{\circ} \mathrm{C}$, there was a separate spherical cell. With the increase of temperature, cells gradually expanded and connected to the adjacent cell to form a polyhedral spherical cell,

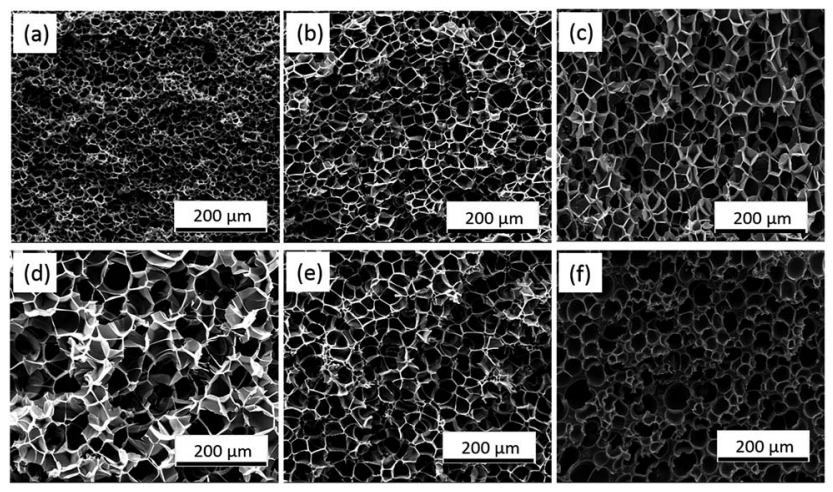

Fig. 5 SEM pictures of PSU foams at different foaming temperatures with $\mathrm{CO}_{2}$ concentration (7\%): (a) $170{ }^{\circ} \mathrm{C}$, (b) $180{ }^{\circ} \mathrm{C}$, (c) $190{ }^{\circ} \mathrm{C}$, (d) $200^{\circ} \mathrm{C}$, (e) $210^{\circ} \mathrm{C}$, (f) $220^{\circ} \mathrm{C}$. 

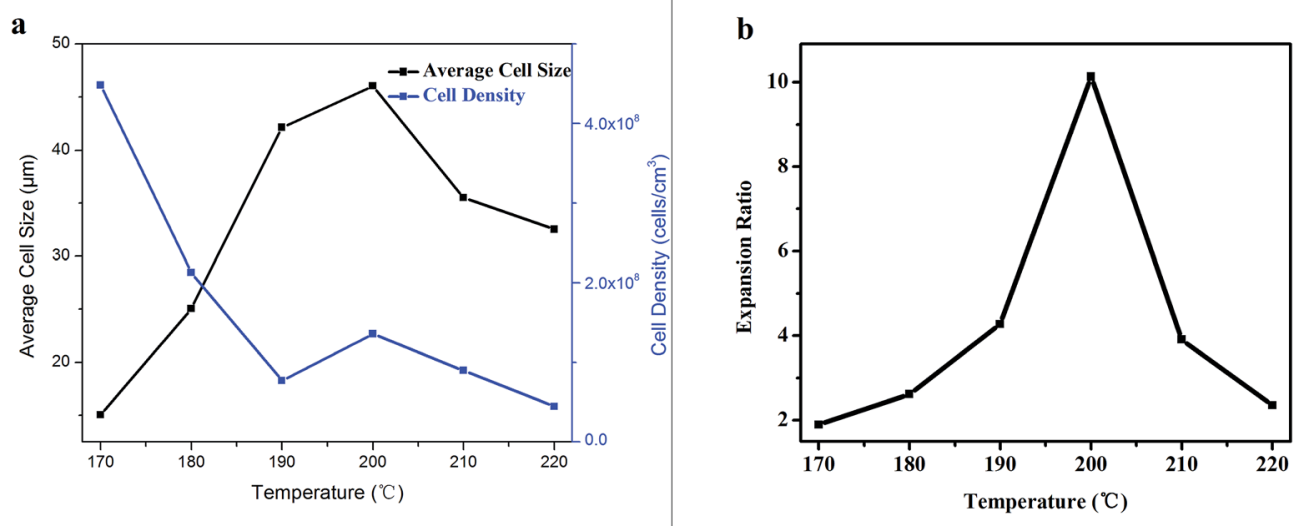

Fig. 6 Average cell size, cell density (a) and expansion ratio (b) of PSU foams at different foaming temperatures with $\mathrm{CO}_{2}$ concentration (7\%).

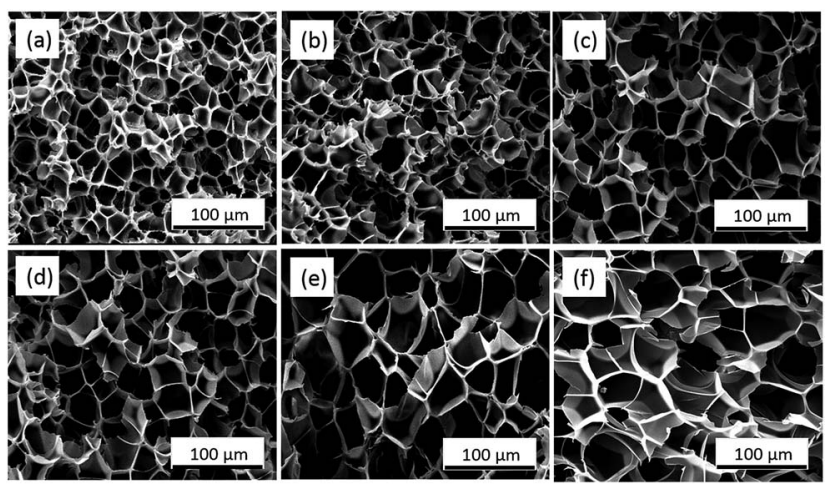

Fig. 7 SEM pictures of PSU foams at different $\mathrm{CO}_{2}$ concentrations with foaming temperature $\left(200^{\circ} \mathrm{C}\right.$ ): (a) $1.8 \%$, (b) $3.3 \%$, (c) $4.4 \%$, (d) $5.3 \%$, (e) $7.0 \%$, (f) $9.0 \%$.

even individual cell had broken and the cell wall was very thin. As the temperature increased again, cell had afresh become a separate spherical cell structure and a thicker cell wall appeared.

Fig. 6 shows average cell diameter, cell density and expansion ratio of PSU foams at different foaming temperatures. With the increase of temperature from $170{ }^{\circ} \mathrm{C}$ to $200{ }^{\circ} \mathrm{C}$, the average cell size and expansion ratio showed an increasing trend after the first increase, while the cell density decreased slowly. As we all know, that the polymer viscosity and melt strength decreased with the temperature increasing is the main reason. Thus, the bubble growth resistance decreased with the temperature increasing, which would lead to a bigger cell diameter. During the bubble growth process, the big bubbles merged with each other caused by touching. And there would be bigger and fewer bubble because of the above merging, which means high expansion ratio. However, as the temperature further rose, the viscosity and melt strength of polymer continuously reduced, which will result the bubble easy to collapse, as shown in Fig. $5 \mathrm{f}$. Thus, the expansion ratio, average cell size, and cell density became smaller, while cell wall became thicker.

3.3.2. Influence of $\mathrm{CO}_{2}$ concentration. Another crucial influence factor for foaming is the $\mathrm{CO}_{2}$ concentration in the polymer matrix during the foaming stage. ${ }^{17}$ There is a strong plasticizing effect on the polymer offered by $\mathrm{CO}_{2}$, but the plasticization is not obvious after $\mathrm{CO}_{2}$ concentration increases to $5 \%$ in the high pressure capillary test. As for foaming, $\mathrm{CO}_{2}$ is not only a plasticizer but also a foaming agent. Thus, more $\mathrm{CO}_{2}$ in
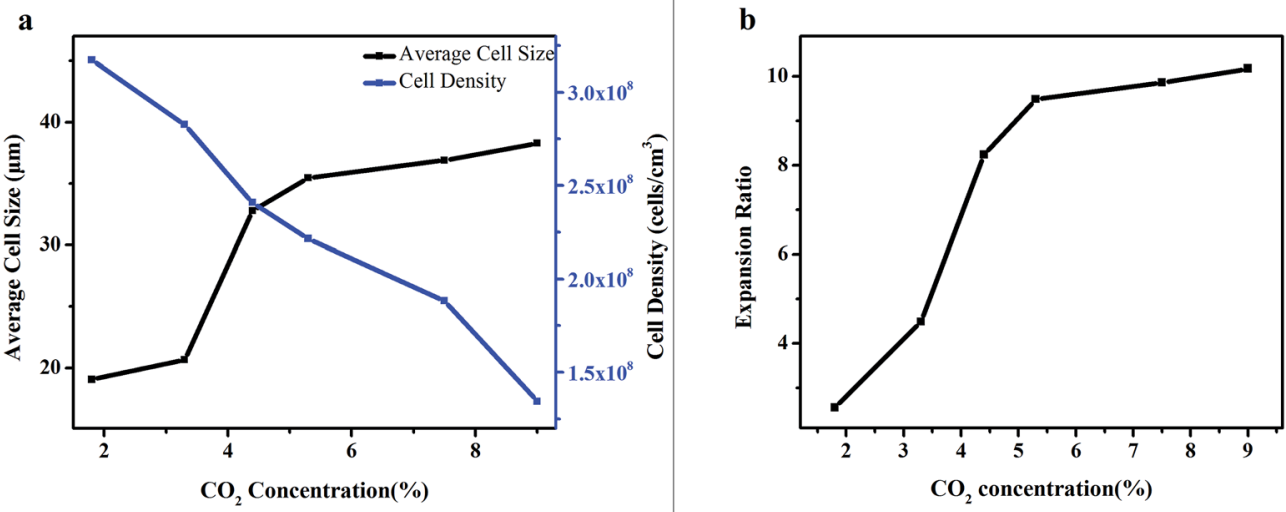

Fig. 8 Average cell size, cell density (a) and expansion ratio (b) of PSU foams at different $\mathrm{CO}_{2}$ concentrations with foaming temperature (200 ${ }^{\circ} \mathrm{C}$ ). 


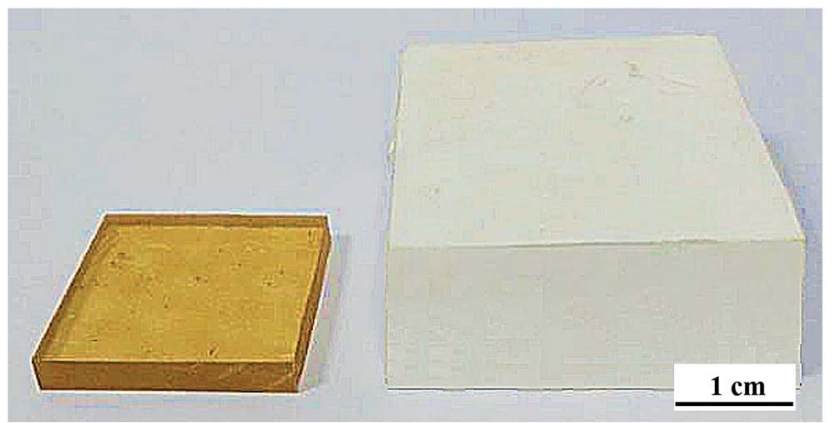

Unfoamed sample

Foamed sample

Fig. 9 Photograph of unfoamed sample and foamed sample.

the polymer means more nucleating points, which will form different cellular structures. Fig. 7 shows the SEM pictures of PSU foams at different $\mathrm{CO}_{2}$ concentrations. With the increase of $\mathrm{CO}_{2}$ concentration, cell structures changed obviously at the $\mathrm{CO}_{2}$ concentration below 5\%. Bubble hole became polyhedral spherical bubble hole from foregoing spherical bubble hole. However, under the $\mathrm{CO}_{2}$ concentrations above $5 \%$, the bubble pore structure didn't obviously change.

In addition, as shown in Fig. 8, with the increase of $\mathrm{CO}_{2}$ concentration, the cell density decreased gradually, while the average cell size and expansion ratio showed a rapid increasing tendency with the $\mathrm{CO}_{2}$ concentration from $1 \%$ to $5 \%$ and then kept stable with the $\mathrm{CO}_{2}$ concentration from $5 \%$ to $9 \%$. This was in accordance with the viscosity of the polymer in Fig. 4 . When the $\mathrm{CO}_{2}$ concentration was below 5\%, the higher the $\mathrm{CO}_{2}$ concentrations, the more obvious plasticizing effect for polymer, so the average cell size and expansion ratio of polymer increased. However, when the $\mathrm{CO}_{2}$ concentration was above $5 \%$, the viscosity of polymer remains stable, so the average cell size and expansion ratio also remained stable.

\subsection{Macromorphology and properties}

Compared with the unfoamed sample, there is a great change for foamed sample after foaming on the macromorphology. As shown in Fig. 9, it can be clearly found that unfoamed sample was amber-like and transparent, while the foamed sample looked white and volume increases greatly.
Next, different kinds of properties of PSU foams were tested in the research, such as mechanical properties, thermal properties, and flame retardancy, as shown in Table 2. For mechanical properties of polymer foam, compression strength $(P)$ and tensile strength $(\sigma)$ were measured respectively. And thermal conductivity $(\lambda)$, heat desorption temperature (HDT) and limit oxygen index (LOI) were tested to characterise the thermal properties and flame retardancy of the foam. Compared with general plastic foams, PSU foam in the study had lots of outstanding performance, such as mechanical properties at least an order of magnitude higher than that of other general plastic foams and heat distortion temperature up to $168^{\circ} \mathrm{C}$. Especially, the LOI of the PSU foam was $27.5 \%$, means that it belonged to a flame retardant material. What's more, compared with other commercial special engineering plastic foams as shown in Table 2, the properties of PSU foam have been close to or even exceeded part properties of them.

\section{Conclusions}

High expansion ratio PSU foam has been prepared by using a new kind of PSU foaming method with $\mathrm{scCO}_{2}$ as foaming agent assisted mold pressing. There was a great reduction for the $T_{\mathrm{g}}$ by HP-DSC test and decrease for the viscosity by high pressure capillary test, which indicated that it is feasible for PSU to foam by supercritical $\mathrm{CO}_{2}$. In addition, the foaming process parameters were also obtained by $\mathrm{CO}_{2}$ adsorption test.

PSU foams with various average cell sizes, cell densities, and expansion ratios have been attained by tailoring the foaming temperature and $\mathrm{CO}_{2}$ concentration individually. At the foaming temperature from $170{ }^{\circ} \mathrm{C}$ to $200{ }^{\circ} \mathrm{C}$, average cell size and expansion ratio increased, while cell density decreased. After that, all were opposite with before as the temperature from $200{ }^{\circ} \mathrm{C}$ to $220{ }^{\circ} \mathrm{C}$. Of course, there existed the best foaming temperature at $200{ }^{\circ} \mathrm{C}$. When the $\mathrm{CO}_{2}$ concentration increased, average cell size and expansion ratio increased rapidly with $\mathrm{CO}_{2}$ concentration from $1 \%$ to $5 \%$ and then kept stable above $5 \%$, while cell density gradually decreased during the $\mathrm{CO}_{2}$ concentration increasing.

Compared with general plastic foams, there were excellent mechanical properties for the PSU foam such as high compression strength and tensile strength, and there were also other excellent performances like high heat distortion

Table 2 Mechanical properties, thermal properties and flame resistance of different kinds of foams

\begin{tabular}{|c|c|c|c|c|c|c|}
\hline & $\operatorname{EPS}^{a}$ & Plastazote $®$ HD110 $0^{b}$ & Airex® C70 PVC $^{c}$ & Airex® R82 $\mathrm{PEI}^{c}$ & Rohacell@ $\mathrm{S}$ PMI ${ }^{d}$ & PSU \\
\hline$\rho\left(\mathrm{kg} \mathrm{m}^{-3}\right)$ & $16-64$ & 110 & 100 & 110 & 110 & 110 \\
\hline$P(\mathrm{MPa})$ & $0.09-0.55$ & 0.78 & 2.0 & 1.4 & 2.8 & 2.18 \\
\hline $\operatorname{HDT}\left({ }^{\circ} \mathrm{C}\right)$ & $60-70$ & 100 (ref. 28) & 120 & 190 & $200-220$ & 168 \\
\hline$\lambda\left(\mathrm{W} \mathrm{m}{ }^{-1} \mathrm{~K}^{-1}\right)$ & $0.031-0.038$ (ref. 29) & $0.037-0.042$ (ref. 30) & 0.035 & 0.040 & 0.038 & 0.042 \\
\hline LOI (\%) & 18 (ref. 8) & 17.5 (ref. 31) & 30 & 35 & 29 & 27.5 \\
\hline
\end{tabular}

${ }^{a}$ Data come from product specification of EPS Industry Alliance, in America. ${ }^{b}$ Data come from product specification of Zotefoams company, in England. ${ }^{c}$ Data come from product specification of Airex company, in Switzerland. ${ }^{d}$ Data come from product specification of Rohm company, in Germany. 
temperature, good thermal conductivity and perfect flame retardancy. Moreover, the properties of PSU foam have been close to or even more than part properties of other commercial special engineering plastic foams. The results demonstrate that PSU foam in the study is promising to be used as a kind of substitute material in electric wire and cable industry, railway and steamer transportation, oil and gas platform, military and other fields.

\section{Conflicts of interest}

There are no conflicts to declare.

\section{Acknowledgements}

This work was financially supported by National Natural Science Foundation of China (51573117, 51433006, 51721091), Science and technology support program of Sichuan Province (2015GZ0067) and State key laboratory polymer materials engineering (No. sklpme2016-3-01).

\section{References}

1 J. Miltz and G. Gruenbaum, Polym. Eng. Sci., 1981, 21, 10101014.

2 T. Tanaka, T. Aoki, T. Kouya, M. Taniguchi, W. Ogawa, Y. Tanabe and D. R. Lloyd, Desalin. Water Treat., 2010, 17, 37-44.

3 J. Miltz, O. Ramon and S. Mizrahi, J. Appl. Polym. Sci., 1989, 38, 281-290.

4 R. Williams and C. Aldao, Polym. Eng. Sci., 1983, 23, 293-298.

5 D. Kajiya, M. Imanishi and K.-i. Saitow, J. Phys. Chem. B, 2016, 120, 785-792.

6 A. Cummings and S. P. Beadle, J. Sound Vib., 1994, 175, 115133.

7 X. C. Bian, J. H. Tang, Z. M. Li, Z. Y. Lu and A. Lu, J. Appl. Polym. Sci., 2007, 104, 3347-3355.

8 G. Wang, X. Chen, P. Liu and S. Bai, J. Appl. Polym. Sci., 2016, 134, DOI: $10.1002 / a p p .44356$.

9 C. Okolieocha, T. Köppl, S. Kerling, F. J. Tölle, A. Fathi, R. Mülhaupt and V. Altstädt, J. Cell. Plast., 2015, 51, 413-426.

10 H. Demir, M. Sipahioglu, D. Balkose and S. Ulku, J. Mater. Process. Technol., 2008, 195, 144-153.
11 E. Mahmoudi, L. Y. Ng, M. M. Ba-Abbad and A. W. Mohammad, Chem. Eng. J., 2015, 277, 1-10.

12 S. Habibi, A. Nematollahzadeh and S. A. Mousavi, Chem. Eng. J., 2015, 267, 306-316.

13 S. Aktas, H. Gevgilili, D. Kalyon, I. Küçük and A. Sunol, Hum. Mol. Genet., 2013, 20, 3606-3619.

14 S. Pourmortazavi and S. Hajimirsadeghi, Ind. Eng. Chem. Res., 2005, 44, 6523-6533.

15 Z. Ma, G. Zhang, X. Shi, Q. Yang, J. Li, Y. Liu and X. Fan, J. Appl. Polym. Sci., 2015, 132, DOI: 10.1002/app.42634.

16 L. Sorrentino, M. Aurilia and S. Iannace, J. Appl. Polym. Sci., 2011, 122, 3701-3710.

17 H. Guo, A. Nicolae and V. Kumar, J. Polym. Sci., Part B: Polym. Phys., 2015, 53, 975-985.

18 M. Sauceau, J. Fages, A. Common, C. Nikitine and E. Rodier, Prog. Polym. Sci., 2011, 36, 749-766.

19 B. Krause, K. Diekmann, N. Van der Vegt and M. Wessling, Macromolecules, 2002, 35, 1738-1745.

20 H. Sun, J. E. Mark, S. C. Tan, N. Venkatasubramanian, M. D. Houtz, F. E. Arnold and C. Y. Lee, Polymer, 2005, 46, 6623-6632.

21 S. Kazarian, M. Vincent, F. Bright, C. Liotta and C. Eckert, J. Am. Chem. Soc., 1996, 118, 1729-1736.

22 D. Kajiya, M. Imanishi and K. I. Saitow, J. Phys. Chem. B, 2016, 120, 785.

23 M. A. Jacobs, M. F. Kemmere and J. T. F. Keurentjes, Polymer, 2004, 45, 7539-7547.

24 K. A. Arora, A. J. Lesser and T. J. McCarthy, Macromolecules, 1998, 31, 4614-4620.

25 X. Chen, J. J. Feng and C. A. Bertelo, Polym. Eng. Sci., 2006, 46, 97-107.

26 P. Agarwal, R. Somani, W. Weng, A. Mehta, L. Yang, S. Ran, L. Liu and B. Hsiao, Macromolecules, 2003, 36, 5226-5235.

27 R. Alamo, M. Kim, M. Galante, J. Isasi and L. Mandelkern, Macromolecules, 1999, 32, 4050-4064.

28 C. P. Park, J. Cell. Plast., 2002, 38, 129-138.

29 J. Schellenberg and M. Wallis, J. Cell. Plast., 2010, 46, 209222.

30 J. Martínez-Díez, M. Rodríguez-Pérez, J. De Saja, L. A. Y. Rábago and O. Almanza, J. Cell. Plast., 2001, 37, 21-42.

31 Z. Wang, B. Qu, W. Fan and P. Huang, J. Appl. Polym. Sci., 2001, 81, 206-214. 